\title{
Sosialisasi Pentingnya Mencapai Financial Freedom dalam Mengatur Keuangan di Masa Pandemi Bagi UMKM
}

\section{Izdihar Naufal Afaf, Reni Yendrawati*}

Program Studi Akuntansi, Fakultas Bisnis dan Ekonomika, Universitas Islam Indonesia, Yogyakarta, Indonesia.

*Corresponding author: reni.yendrawati@uii.ac.id

\section{Abstrak}

Pandemi Covid-19 ini menyebabkan 40\% UMKM di Indonesia terpaksa gulung tikar, karena salah satu penyebabnya adalah minimnya pengetahuan para pemilik UMKM dalam mengelola keuangan mereka. Dalam realitanya bahwa Produk Domestik Bruto (PDB) di Indonesia sendiri dipengaruhi oleh para pemilik UMKM sebesar 61,07\%. Metode pelaksanaan sosialisasi ini dilakukan dengan melakukan pengamatan, wawancara secara langsung, dan pencarian data melalui internet sebagai dasar penyusunan video pemberdayaan. Hasil yang diperoleh adalah bahwa masih banyak pelaku UMKM di Kelurahan Sraten, Kecamatan Gatak, Kabupaten Sukoharjo, Jawa Tengah. yang belum dapat mengoptimalkan pengelolaan keuangan mereka dikarenakan minimnya pengetahuan mengenai financial freedom yang menyebabkan kurang maksimalnya keuntungan yang didapat. Dari permasalahan tersebut dibuatlah video pemberdayaan mengenai financial freedom berisi definisi financial freedom itu sendiri dan tujuh langkah yang dapat dilakukan untuk mencapai financial freedom.

Kata kunci: Financial freedom; Masyarakat umum; dan Pelaku UMKM

\section{Abstract}

The Covid-19 pandemic has forced 40\% of MSMEs in Indonesia to go out of business, because one of the reasons is the lack of knowledge of MSME owners in managing their finances. In reality, the Gross Domestic Product (GDP) in Indonesia itself is influenced by MSME owners by $61.07 \%$. The method of implementing this socialization was carried out by observing, direct interviews, and searching for data via the internet as the basis for compiling empowerment videos. The results obtained are that there are still many MSME owners, in Sraten Urban Village, Gatak District, Sukoharjo Regency, Central Java who have not been able to optimize their financial management due to the lack of knowledge about financial freedom which causes the maximum profit to be obtained. From these problems, an empowerment video about financial freedom was made containing the definition of financial freedom itself and seven steps that can be taken to achieve financial freedom.

Keywords: Financial Freedom; General Public; and MSME's Owner's

Cite this article: Afaf, I. N., \& Yendrawati, R. (2021). Sosialisasi Pentingnya Mencapai Financial Freedom dalam Mengatur Keuangan di Masa Pandemi Bagi UMKM. Rahmatan Lil'alamin Journal of Community Services, 1 (1).

\section{Pendahuluan}

Di masa pandemi ini banyak bermunculan UMKM yang ada di sekitar kita. Ketua Komite Tetap UKM dan Koperasi Kadin Indonesia menyatakan bahwa dalam realitanya juga masih banyak UMKM yang berakhir gulung tikar sebesar $40 \%$ dikarenakan dampak pandemi ini, salah satu penyebabnya adalah kurangnya pengetahuan akan manajemen usaha (Ariesta, 2021). 
Selain itu masih banyak juga UMKM yang tidak bisa berkembang dengan baik, sehingga usaha tersebut hanya diam dalam skala menengah saja. Mereka tidak mengetahui dan kurangnya pengetahuan mereka bagaimana mengelola atau menjalankan usaha dengan baik dan benar. Dari kondisi tersebut, maka diadakanlah kegiatan sosialisasi mengenai pengelolaan modal usaha yang berfokus kepada mencapai financial freedom.

Tujuan dari dilaksanakannya kegiatan tersebut adalah untuk memberikan pengetahuan kepada masyarakat secara umum dan para pelaku UMKM khususnya bidang penggilingan padi mengenai pengertian financial freedom atau kebebasan keuangan dan langkah-langkah untuk dapat mencapai financial freedom tersebut.

Menurut Silaya, (2020) seseorang dapat dikatakan sehat keuangannya jika dalam mengelola keuangannya menggunakan perencanaan dengan melakukan analisis yang tepat dan dengan tujuan keuangan yang jelas. Beberapa penyebab seseorang tidak bisa mencapai kesehatan keuangan karena pengeluaran lebih besar daripada pendapatan, hutang konsumtif yang tidak terkendali, tidak menyimpan dana darurat dan dana tabungan, tidak adanya perencanaan keuangan dll.

Menurut Kementerian Koperasi \& UKM, (2021) dalam website resmi Kementerian Koordinator Bidang Perekonomian Republik Indonesia dalam siaran pers HM.4.6/103/SET.M.EKON.3/05/2021 sendiri mengatakan bahwa UMKM memiliki pengaruh yang besar terhadap Produk Domestik Bruto (PDB) sebesar 61,07\%, menjadikan UMKM sebagai pilar penting perekonomian di Indonesia. Sungguh disayangkan jika pengelolaan keuangan para UMKM tidak berjalan beriringan dengan pengaruhnya terhadap PDB di Indonesia.

\section{Metode Pelaksanaan}

Metode yang digunakan dalam pengumpulan data penelitian ini adalah dengan teknik pengamatan langsung, wawancara secara langsung, dan dari sumber sekunder seperti dari internet. Dalam pengamatan langsung penulis memilih daerah pengamatan yaitu sekitar Kelurahan Sraten, alasan dipilihnya tempat tersebut karena banyaknya UMKM yang serupa yaitu penggilingan padi. Pengambilan data dilakukan dengan mewawancarai salah satu narasumber yaitu Ibu Erni Hartawati selaku salah satu pemilik UMKM penggilingan padi, sebagai data primer dan melalui internet sebagai data sekunder tambahan.

\section{Pembahasan}

Tabel di bawah adalah informasi yang diperoleh dari hasil pengamatan. Kemudian hasil dari pengklasifikasian data tersebut di analisis. Hasil analisisnya adalah subjek atau objek pengamatan adalah pengimplementasian dari financial freedom yang belum maksimal diterapkan oleh para pelaku UMKM di sekitar Kelurahan Sraten. Identifikasi masalahnya adalah kurangnya pengetahuan mengenai financial freedom menyebabkan kurang 
maksimalnya implementasi financial freedom oleh para pelaku UMKM. Penyebab permasalahan tersebut karena kurangnya pengetahuan yang dimiliki dan rasa takut masyarakat dalam bertindak untuk maju karena risiko yang akan dihadapi. Akibat yang ditimbulkan adalah kurang maksimalnya UMKM dalam mengelola keuangan, sehingga minimnya keuntungan yang didapat, padahal mereka bisa mendapat keuntungan yang lebih dari pengimplementasian financial freedom tersebut. Dari permasalahan tersebut diambillah rumusan masalah sebagai berikut, para pemilik UMKM belum dapat mengoptimalkan pengelolaan uang mereka karena keterbatasan pengetahuan mereka mengenai financial freedom, sehingga kurang maksimalnya keuntungan yang didapat menyebabkan jauhnya kata financial freedom dalam mencapainya. Kemudian alternatif pemecahan masalah yang diberikan adalah dengan mensosialisasikan materi mengenai bagaimana caranya mencapai financial freedom dengan maksimal dan mengajarkan Langkah-langkah yang bisa ditempuh untuk mencapai financial freedom tersebut.

\begin{tabular}{ll}
\hline No & Data \\
\hline 1 & $\begin{array}{l}\text { Terdapat beberapa UMKM yang sejenis di sekitar Kelurahan Sraten } \\
\text { terkait penggilingan padi }\end{array}$ \\
2 & $\begin{array}{l}\text { Dampak dari masa pandemi menyebabkan produksi lesu dan tidak } \\
\text { maksimal di UMKM tersebut }\end{array}$ \\
3 & $\begin{array}{l}\text { Bantuan sosial dari pemerintah menambah lesunya produksi di } \\
\text { UMKM karena tidak mendapat pesanan untuk produksi }\end{array}$ \\
4 & $\begin{array}{l}\text { Hanya UMKM tertentu yang mendapat pesanan produksi dari } \\
\text { pemerintah untuk bantuan sosial. Namun dari UMKM tersebut tidak }\end{array}$ \\
5 & $\begin{array}{l}\text { ada yendapg dari Kelurahan Sraten } \\
\text { jarang terjadi di UMKM }\end{array}$ \\
6 & $\begin{array}{l}\text { Di masa pandemi ini UMKM tetap berproduksi namun dengan skala } \\
\text { yang kecil daripada di luar masa pandemi }\end{array}$ \\
7 & $\begin{array}{l}\text { Adanya kerjasama antar UMKM dan terdapat kelompok arisan yang } \\
\text { berfungsi selain silaturahmi juga saling menyokong sesama }\end{array}$ \\
8 & $\begin{array}{l}\text { Kurang maksimalnya implementasi financial freedom karena } \\
\text { pengetahuan yang minim dari masyarakat pelaku UMKM }\end{array}$ \\
\hline
\end{tabular}

Menurut Orman, (2000), financial freedom adalah situasi dimana Anda terbebas dari rasa takut dan rasa cemas atas keuangan Anda akan habis dan memiliki kebebasan atas kekuatan keuangan yang dimiliki tanpa harus dengan bekerja lebih keras.

Langkah-langkah yang dapat ditempuh untuk mencapai financial freedom adalah sbb:

1. Membuat rencana keuangan

Rencana keuangan sendiri adalah susunan perencanaan yang digunakan untuk mengalokasikan keuangan pribadi untuk memenuhi tujuan keuangan. Tujuan keuangan sendiri memiliki strategi berupa saving, living, playing, dan caring. 
2. Bebas dari hutang konsumtif

Hutang konsumtif sendiri adalah hutang yang digunakan hanya untuk memenuhi kebutuhan konsumsi yang biasanya tidak mendesak. Hutang ini lebih mengarah ke hal yang negatif karena penggunaannya hanya mengurangi pendapatan saja.

3. Memiliki dana darurat

Dana darurat berbeda dengan dana tabungan, dana darurat sendiri adalah dana yang disimpan untuk keadaan yang mendesak atau darurat yang kejadiannya tidak terduga. Seperti di saat pandemi ini pemutusan hubungan kerja atau PHK marak terjadi, di saat seperti inilah dana darurat digunakan.

4. Memiliki investasi

Investasi berarti berkorban atas sumber daya yang dimiliki saat ini yang diharapkan di masa mendatang akan mendapatkan keuntungan lebih. Investasi sendiri berguna untuk melawan laju inflasi dan sebagai pendapatan pasif.

5. Memiliki aset produktif

Aset produktif sendiri adalah aset yang didapat dari hasil investasi aset berwujud. Contoh dari aset produktif sendiri adalah properti, emas, mesin, dll. Sehingga dalam mempersiapkan asset produktif perlu perhitungan yang benar agar keuntungan yang didapat lebih maksimal.

6. Mangatur pendapatan pasif

Pendapatan pasif adalah pendapatan yang didapatkan dengan cara melakukan aktifitas seminim mungkin tanpa perlu bekerja lebih keras untuk mendapatkannya dengan tanpa berperan aktif di dalamnya, contohnya investasi tadi, dari hasil investasi tersebut pendapatan yang diperoleh dapat dialokasikan untuk menambah modal usaha, menambah dana daarurat, atatupun untuk diinvestasikan kembali.

7. Pengembangan potensi diri

Pengembangan potensi berguna untuk mencapai tujuan tertentu jika dilatih dan diasah dengan benar. Pengembangan dapat dimulai dengan mencari kelebihan diri yang kemudian dilanjutkan dengan menentukan tujuan hidup. Financial freedom tidak hanya sebatas menjadi kaya, namun bagaimana kita dalam mengelola keuangan dalam jangka waktu lama.

Pembuatan video sendiri dibuat dengan konsep kegiatan pemberdayaan masyarakat berupa video materi berisi latar belakang topik, pengenalan singkat mengenai financial freedom, langkah-langkah mencapai financial freedom, dan kesimpulan video pemberdayaan. Perancangan video materi dimulai dengan pembuatan story board berupa time frame setiap bagian dalam video materi, lalu dilakukan pengumpulan materi-materi yang kemudian disusun dalam file power point dalam bentuk poin-poin apa saja yang akan ditampilkan dalam video materi, kemudian dalam file word dibuat narasi apa saja yang akan disampaikan dalam video materi. Pembuatan video pemberdayaan masyarakat sendiri menggunakan aplikasi Videoscribe. 


\section{Kesimpulan}

Pentingnya pengetahuan mengenai financial freedom di masa pandemi ini perlu diterapkan dalam kehidupan, karena hal tersebut mampu memberi ketenangan hidup dalam keuangan. Financial freedom juga sangat penting untuk para pelaku UMKM karena hal tersebut untuk meminimalisir terjadi nya gulung tikar. Dengan kegiatan sosialisasi ini diharapkan agar para masyarakat terutama pelaku UMKM dapat mengelola keuangan mereka dengan baik, sehingga dapat lebih memajukkan perekonomian Indonesia dan dapat memakmurkan masyarakat semua. Saran untuk pengabdian masyarakat berikutnya untuk lebih bisa menggali permasalahan masyarakat dalam hal mengelola keuangan dan mengembangkan materi sosialisasi ke depannya dan lebih terperinci dalam menjelaskan langkah-langkah mencapai financial freedom tersebut. Selain itu diharapkan pengabdian berikutnya dapat dilakukan secara langsung sehingga materi yang disampaikan dapat diterima dengan baik.

\section{Referensi}

Ariesta, A. (2021). 40 Persen Pelaku UMKM Putuskan Gulung Tikar Akibat

Terdampak Pandemi. idxchannel.com. Diambil dari https://www.idxchannel.com/economics/40-persen-pelaku-umkmputuskan-gulung-tikar-akibat-terdampak-pandemi

Kementerian Koperasi \& UKM, (2021). UMKM Menjadi Pilar Penting dalam

Perekonomian Indonesia. Ekon.go.id. Diambil dari https://ekon.go.id/publikasi/detail/2969/umkm-menjadi-pilarpenting-dalam-perekonomian-indonesia

Orman, S. (2000). Nine Steps to Financial Freedom. Three Rivers Press (CA).

Silaya, M. A. (2020). Financial Health: Suatu Kajian Pustaka. XIV, 99-110. 